EREM 72/3

Journal of Environmental Research, Engineering and Management

Vol. 72 / No. 3 / 2016

pp. $18-26$

DOI 10.5755/j01.erem.72.3.12790

(c) Kaunas University of Technology
Neutronic Study of Burnup, Radiotoxicity, Decay Heat and Basic Safety

Parameters of Mono-Recycling of Americium in French Pressurised Water Reactors

\title{
Neutronic Study of Burnup, Radiotoxicity, Decay Heat and Basic Safety Parameters of Mono-Recycling of Americium in French Pressurised Water Reactors
}

\section{Robert Bright Mawuko Sogbadji}

Ghana Atomic Energy Commission, National Nuclear Research Institute

Nuclear Reactors Research Centre, P.O. Box LG80 Legon, Ghana

\section{Sylvain David}

Institut de Physique Nucleaire

15 rue Georges Clemenceau, 91406 - ORSAY Cedex - France

Edward Akaho, Benjamin Jabez Botwe Nyarko

University of Ghana, Graduate School of Nuclear and Allied Science

PO Box AE1, Atomic, Ghana

Corresponding author: robertmawuko@gmail.com

Robert Bright Mawuko Sogbadji, Ghana Atomic Energy Commission, National Nuclear Research Institute Ministry of Power, P. O. Box MB330, , Ministries Post Office, Accra - Ghana 
The reprocessing of actinides with long half-life has been non-existent except for plutonium (Pu). This work looks at reducing the actinides inventory nuclear fuel waste meant for permanent disposal. The uranium oxide fuel (UOX) assembly, as in the open cycle system, was designed to reach a burnup of $46 \mathrm{GWd} / \mathrm{T}$ and $68 \mathrm{GWd} / \mathrm{T}$ using the MURE code. The MURE code is based on the coupling of a static Monte Carlo code and the calculation of the evolution of the fuel during irradiation and cooling periods. The MURE code has been used to address two different questions concerning the mono-recycling of americium (Am) in present French pressurised water reactors (PWR). These are reduction of americium in the clear fuel cycle and the safe quantity of americium that can be introduced into mixed oxide (MOX) as fuel. The spent UOX was reprocessed to fabricate MOX assemblies, by the extraction of plutonium and addition of depleted uranium to reach burnups of $46 \mathrm{GWd} / \mathrm{T}$ and $68 \mathrm{GWd} / \mathrm{T}$, taking into account various cooling times of the spent UOX assembly in the repository. The effect of cooling time on burnup and radiotoxicity was then ascertained. After 30 years of cooling in the repository, the spent UOX fuel required a higher concentration of Pu to be reprocessed into MOX fuel due to the decay of Pu-241. Americium, with a mean half-life of 432 years, has a high radiotoxicity level, high mid-term residual heat and is a precursor for other long-lived isotopes. An innovative strategy would be to reprocess not only the plutonium from the UOX spent fuel but also the americium isotopes, which presently dominate the radiotoxicity of waste. The mono-recycling of Am is not a definitive solution because the once-through MOX cycle transmutation of Am in a PWR is not enough to destroy all americium. The main objective is to propose a 'waiting strategy' for both Am and Pu in the spent fuel so that they can be made available for further transmutation strategies. The MOX and americium isotopes (MOXAm) fuel was fabricated to see the effect of americium in MOX fuel on the burnup, neutronic behaviour and radiotoxicity. The MOXAm fuel showed relatively good indicators on both burnup and radiotoxicity. A 68GWd/T MOX assembly produced from a reprocessed fuel spent $46 \mathrm{GWd} / \mathrm{T}$ UOX assembly showed a decrease in radiotoxicity as compared with the open cycle. All fuel types understudied in the PWR cycle showed a good safety inherent feature with the exception of some MOXAm assemblies that have a positive void coefficient in specific configurations, which would not be consistent with safety features.

Keywords: Radiotoxicity, Burnup, AmericiumOxide, Cooling Time.

\section{Introduction}

The cooling time before the heat generation of spent fuel has declined to a level suitable for disposal in a geological repository is between 30 and 50 years. In current reprocessing facilities, used fuel is separated into its three components: uranium, plutonium, both of which can be recycled into fresh fuel, and waste containing fission products and minor actinides (Am, Np, $\mathrm{Cm})$. The plutonium can either be stored or made directly into mixed oxide (MOX) fuel, in which uranium and plutonium oxides are combined. Americium combined in the glasses is produced essentially during the cooling period after irradiation by the decay of $\mathrm{Pu}-241$. Am241 is responsible for the high mid-term residual heat. This is the main dimensioning parameter for geological waste repository. Hence, it will be very interesting to reprocess Am together with Pu to minimize the midterm residual heat and also radiotoxicity of the waste. The vitrified waste is a high quality standardised product well suited for geological disposal. Plutonium in MOX is unstable in storage because of the build-up of americium-241, hence the mono-recycling of americium in the UOX once-through cycle of the pressurised water reactor (PWR) (standard French power reactor) [1-3].

\section{Analytical tool and methods}

Several numerical and computational methods or approaches based on nuclear reactor physics, nuclear engineering and mathematical theories exist for performing reactor analysis. Computational transport methods are basically of two different approaches: stochastic and deterministic.

\section{The MURE (MCNP utility for reactor evolution) code}

The MURE code performs nuclear reactor time evolution using the particle transport code MCNP. It is written 
in an object-oriented framework, and a user can define their own way to interact with the evolution. It can also couple neutronics (with or without fuel burnup) and thermal-hydraulics [4,5]. The MURE code can be used to 'easily' generate MCNP input files using the $\mathrm{C}++$ interface. It constructs a nuclear tree network of radioactive decays and nuclear reactions of all nuclei involved in the evolution. This evolution of nuclear materials is achieved by solving the corresponding Bateman equations [6]

$$
\frac{d N_{i}}{d t}=-\sigma_{i}^{a b s} \Phi N_{i}+\sum_{j \neq 1} \sigma_{j \rightarrow i} \Phi N_{j}-\lambda_{i} N_{i}+\sigma_{i} \lambda_{j \rightarrow i} N_{j}
$$

The Bateman equations are solved in the interval $\Delta t$ with a 4th-order Runge-Kutta method using the flux and reaction rates calculated by MCNP to create new MCNP file at $t_{i}+1=t_{i}+\Delta \mathrm{t}$. Each time MCNP is called, the reactor fuel composition will have changed due to the fission/capture/decay process, which has occurred in the material [6]. The MURE code was used to simulate various configurations of the UOX, MOX and MOXAm as- semblies to achieve burnups of $46 \mathrm{GWd} / \mathrm{t}$ and $68 \mathrm{GWd} / \mathrm{t}$. Cooling periods of 5 years and 30 years of spent UOX fuel assemblies were considered for the reprocessing of the americium of the spent UOX fuel. These years were chosen to simulate early reprocessing and late reprocessing of the spent UOX fuel. The radiotoxicity of various fuel configurations was investigated using the MURE code and analysed.

\section{Burnup}

The burnup of the reactor fuel can be increased by refuelling used assemblies (online or at shutdown), core fuel assembly shuffling and control adjustment. Use of irradiated assembly brings about lowering the criticality. In order to compensate the sub-criticality of old assemblies, new assemblies must be introduced into the core to keep the core critical.

\section{The quadratic approach}

The linear assumption did not strictly fit burnups with low Pu quality and high Pu concentration of the MOX(Am) fuel, hence the quadratic approach.

\section{Fig. 1}

Principle of fuel evolution in MURE

[6]

Fig. 2

Linear curve fitting of MOXAm assembly burnup
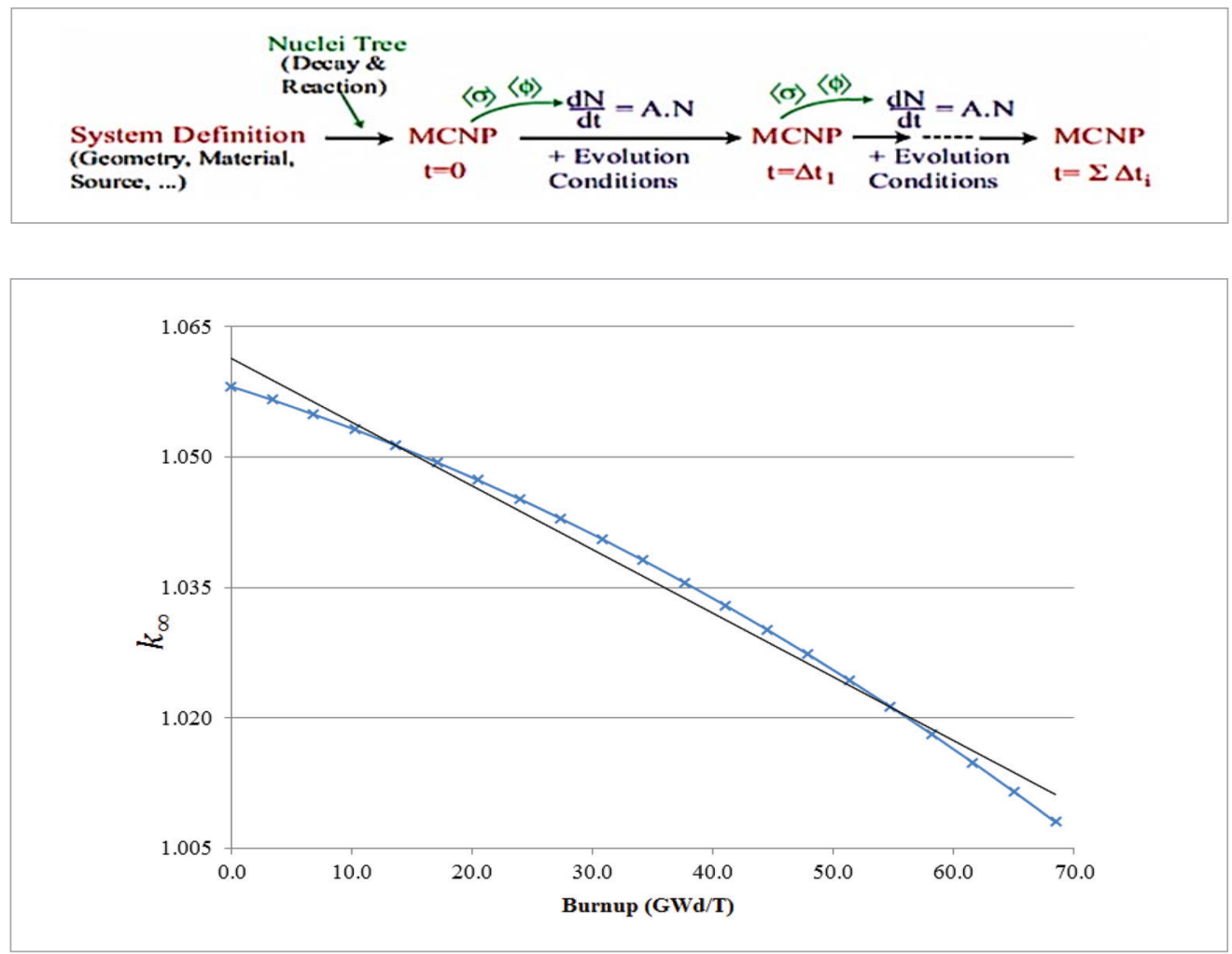
As shown in Fig. 3, the burnup curve fitting of $\operatorname{MOX}(\mathrm{Am})$ assembly to reach $68 \mathrm{GWd} / \mathrm{T}$ is not in agreement with linear fitting. The quadratic approach is adopted in all burnup analyses. Thus, assuming a quadratic fitting of the form,

$$
k_{\infty}=k_{\infty}^{o}+\alpha t+\beta t^{2} .
$$

hence

$$
\begin{aligned}
& k_{\infty}^{E O C}=\left[\left(k_{\infty}^{o}+\alpha T\right)+\left(\beta T^{2}+k_{\infty}^{o}+\alpha 2 T+\beta 2 T^{2}\right)+\right. \\
& \left.+\cdots+\left(k_{\infty}^{o}+\alpha N T+\beta N T^{2}\right)\right] / N .
\end{aligned}
$$

Gathering terms by powers of $\mathrm{T}$,

$$
k_{\infty}^{E O C}=k_{\infty}^{o}-\left(\alpha \frac{N+1}{2}\right) T+\beta\left(\frac{N^{2}}{3}+\frac{N}{2}+\frac{1}{6}\right) T^{2} .
$$

Solving for the period of one cycle T,

$$
T=-\frac{3}{2} \frac{\alpha}{\beta} \frac{N+1}{\Omega} \pm\left\{\left(\frac{3}{2} \frac{\alpha}{\beta} \frac{N+1}{\Omega}\right)^{2}-\frac{6}{\Omega} \frac{k_{\infty}^{o}-k_{\infty}^{E O C}}{\beta}\right\}^{1 / 2}
$$

where

$\Omega=2 N^{2}+3 N+1$.

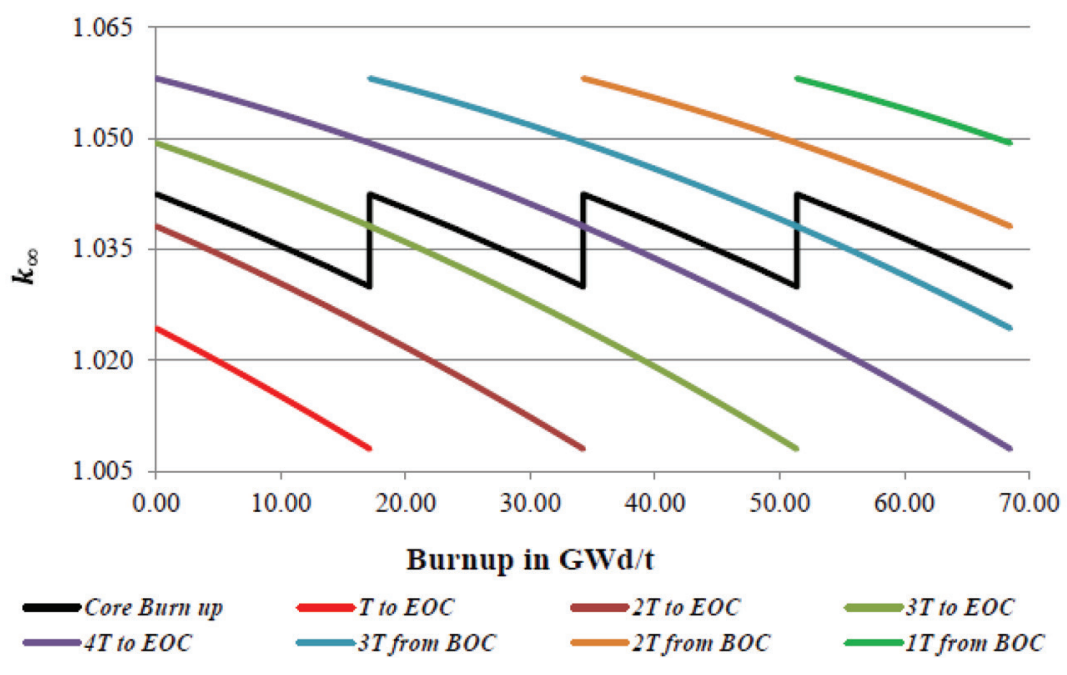

Fig. 3

MOXAm fuel assembly burnup to reach $68 \mathrm{GWd} / \mathrm{t}$ fabricate from a 30-year cooled spent UOX fuel

\section{Radiotoxicity}

The radiotoxicity of a particular nuclide varies depending on whether it is inhaled or ingested. It is influenced by the energy of the rays (nuclear properties), location of absorption in the organism and residence time in the body. Radiotoxicity is a hypothetical dose, expressed in Sieverts (Sv)

$$
\mathrm{R}(\mathrm{Sv})=\mathrm{F}(\mathrm{Sv} / \mathrm{Bq}) \times \mathrm{A}(\mathrm{Bq})
$$

In a decay chain, the radiotoxicity of the mother nuclide is calculated as the sum of all the radiotoxicities of its daughters and expressed as

$$
R(t)=\sum_{i} f_{i} \lambda_{i} N_{i}(t)=\sum_{i} R_{i}(t) .
$$

where $f$ is the dose factor. The dose factors of nuclides are expressed in Table $1[7,8]$. 
Table 1

Compilation of ingestion dose coefficients from ICRP Publication 72, 1996.

\begin{tabular}{c|c|c|c}
\hline \multicolumn{2}{c|}{ Transuranic Element } & \multicolumn{2}{c}{ Long-lived Fission Products } \\
\hline Nuclide & $\begin{array}{c}\text { Ingestion } \\
\text { (nSv/Bq) }\end{array}$ & Nuclide & $\begin{array}{c}\text { Ingestion } \\
\text { (nSv/Bq) }\end{array}$ \\
\hline 1 & 2 & 3 & 4 \\
\hline${ }^{237} \mathrm{~Np}$ & 110 & ${ }^{79} \mathrm{Se}$ & 2.9 \\
\hline${ }^{238} \mathrm{Pu}$ & 230 & ${ }^{90} \mathrm{Sr}$ & 28 \\
\hline${ }^{239} \mathrm{Pu}$ & 250 & ${ }^{93} \mathrm{Zr}$ & 1.1 \\
\hline${ }^{240} \mathrm{Pu}$ & 250 & ${ }^{99} \mathrm{Tc}$ & 0.64 \\
\hline${ }^{241} \mathrm{Pu}$ & 4.8 & ${ }^{107} \mathrm{Pd}$ & 0.037 \\
\hline${ }^{242} \mathrm{Pu}$ & 240 & ${ }^{126} \mathrm{Sn}$ & 4.7 \\
\hline${ }^{241} \mathrm{Am}$ & 200 & ${ }^{129}$ & 110 \\
\hline${ }^{242 \mathrm{~m}} \mathrm{Am}$ & 190 & ${ }^{135} \mathrm{Cs}$ & 2.0 \\
\hline${ }^{243} \mathrm{Am}$ & 200 & ${ }^{137} \mathrm{Cs}$ & 13 \\
\hline${ }^{242} \mathrm{Cm}$ & 12 & & \\
\hline${ }^{243} \mathrm{Cm}$ & 150 & & \\
\hline${ }^{244} \mathrm{Cm}$ & 120 & & \\
\hline${ }^{245} \mathrm{Cm}$ & 210 & & \\
\hline
\end{tabular}

Table 1 shows that plutonium and americium have high dose factors. 241-Pu with a low dose factor will be converted to 241-Am through beta decay after 15 years. This further increases radiotoxicity of spent assemblies being considered for permanent storage. In view of this, this work seeks to reprocess both $\mathrm{Pu}$ and $\mathrm{Am}$ in the spent UOX assembly into MOX and MOXAm fuel, respectively, in order to reduce the radiotoxicity of the spent UOX glasses being stored permanently. This will make these actinides available for incineration when fast reactors come online commercially.

\section{Design consideration}

The N4 type French pressurised water reactor (PWR) design of fuel pins and assemblies was used for this work. This French PWR can be fuelled with a mix core of UOX and MOX assemblies. The larger proportion of plutonium in the core shifts the neutron spectrum towards higher energy levels; this reduces the efficiency of control systems, and the boron concentration is set to $600 \mathrm{ppm}$ as in a PWR moderator. The simulated fuel assembly is $4.75 \%$ the height of the normal fuel assembly with reflected surface at it boundaries to mimic the full length of the fuel assembly.

\section{Results and discussion}

In Fig. 4, the radiotoxicity of the spent UOX fuel and the major contributing nuclides are shown along with the effects on radiotoxicity of various UOX glasses after $\mathrm{Pu}$ and Am extraction from spent UOX assembly for differing durations of pre-cooling.

From Fig. 4 it can be deduced that radiotoxicity levels of spent UOX assemblies will be greatly reduced if $\mathrm{Pu}$ and Am are extracted after 5 years or 30 years and tem-

\section{Fig. 4}

Linear curve fitting of MOXAm assembly burnup

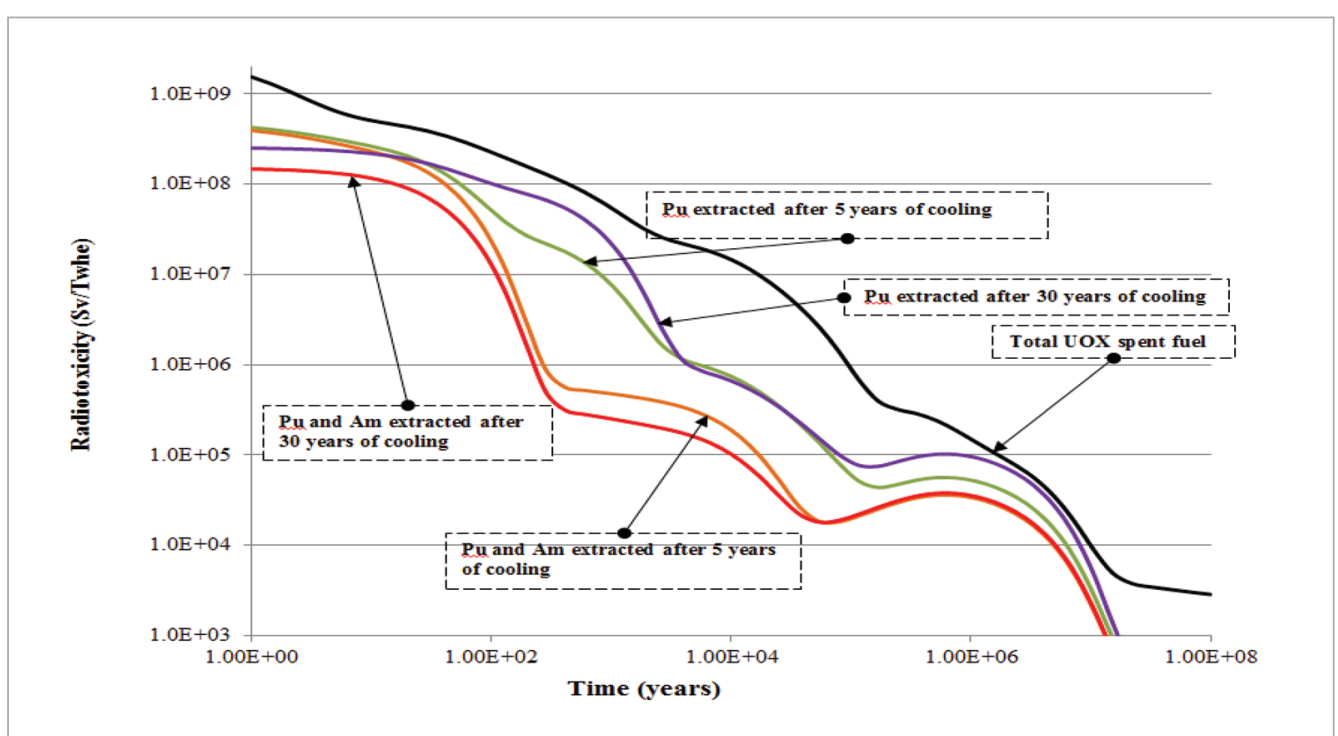


porarily stored for 100 years before permanent storage is considered. All extractions of the nuclides Pu and/or Am for various years show reduction in radiotoxicity as compared with the current French system. Extraction of Pu after 30 years showed an increase in radiotoxicity at 500 years due the beta decay of Pu-241 into Am-241 before the extraction of $\mathrm{Pu}$.

\section{Burnup of MOX and MOXAm fuel}

16 fuel cycles (MOX and MOXAm) were simulated; however, promising MOX(Am) nuclear fuel cycles were featured in this article.

It was observed that bad Pu quality from an UOX cycle as a result of high Am concentration increases Pu concentration. Longer cooling times also increase Pu concentration in both MOX and MOXAm. Short UOX burnup produces high $\mathrm{Pu}$ quality, hence less Pu concentration in MOX to reach a required $\mathrm{BU}$. The total americium production in the current French MOX ((Fr)MOX) cycle is increased by a factor of 1.69 when compared with the UOX once-through cycle at $46 \mathrm{GWd} / \mathrm{T}$.

\section{Radiotoxicity of MOX and MOXAm}

If MOX(Am) fuel is introduced in thermal reactors and we assume the whole world stop using nuclear power, the radiotoxicity of the MOX(Am) spent fuel must be considered. In both cases, radiotoxicity is dominated by minor actinides in the first 100 years, unlike that for the spent UOX fuel, which was dominated by fission products as shown in Fig 4.

Fig. 5. Change in americium concentration during burnup to reach $46 \mathrm{GWd} / \mathrm{t}$.

The MOXAm fuel assemblies in Fig. 5. above show a reduction in americium when incorporated in a fuel assembly to be utilised in a reactor. Approximately 8 spent 5 -year pre-cooled UOX fuel assemblies are required to fabricate similar 46GWd/t MOXAm fuel.

By visual inspection of Fig. 5, the americium content in the MOXAm fuel is reduced, which has a direct reduction on radiotoxicity when this MOXAm fuel is stored in a geological repository as compared with its equivalent spent assemblies of the UOX fuel.

This is due to the hard spectrum of the MOXAm fuel spectrum as shown in Fig. 7. The presence of the relative high population of fast neutrons tends to fission americium.

Similar to Fig. 4, the size of the geological storage would be reduced if the reprocessed UOX glasses were temporarily stored for at least 100 years. The decay heat of the current French UOX glasses can be further reduced if extraction of the actinides considered is done at the right time.

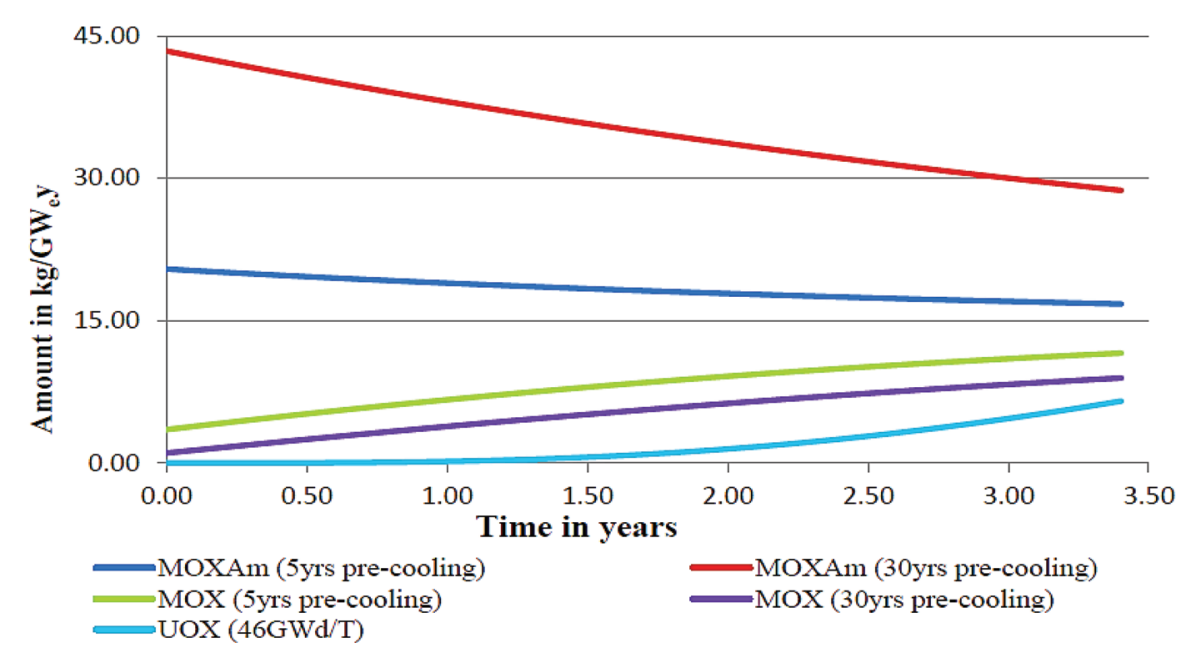

Fig. 5

Change in americium concentration during burnup to reach $46 \mathrm{GWd} / \mathrm{t}$ 
Fig. 6

Geological storage of glasses from UOX reprocessing

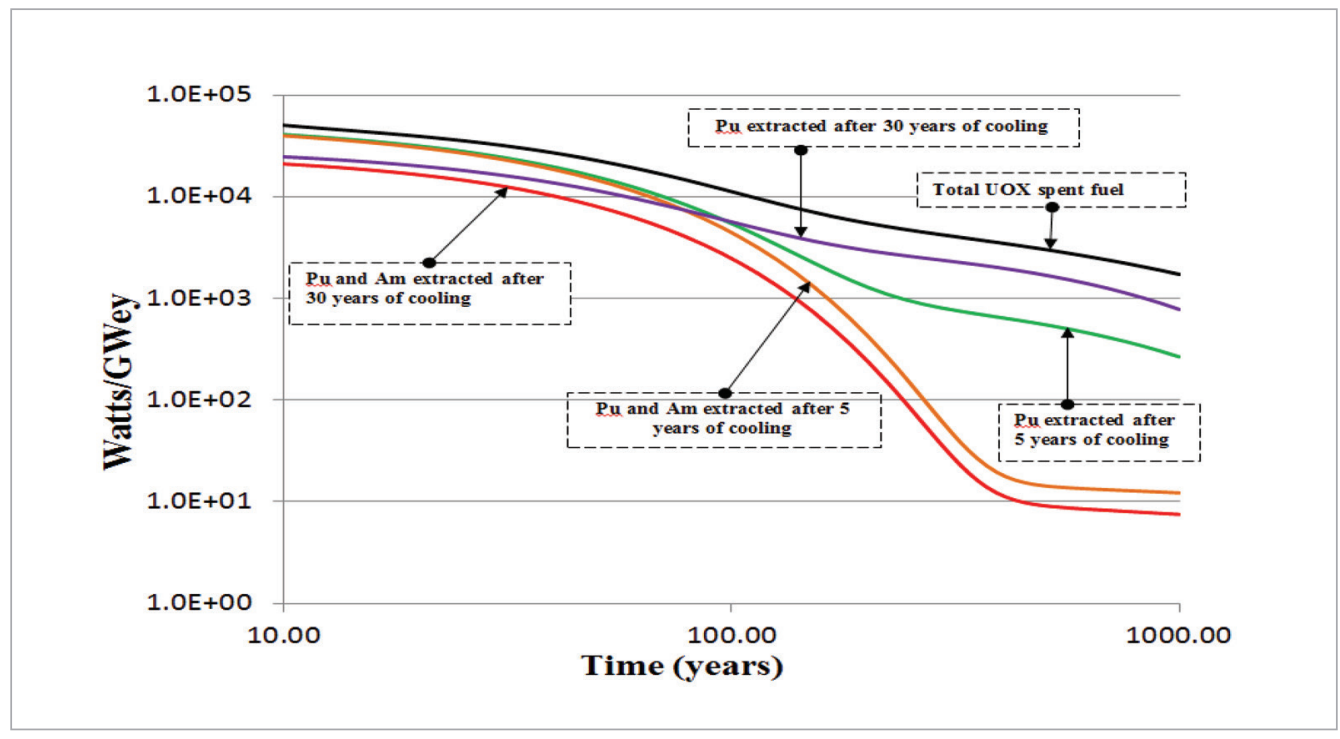

\section{Basic safety analysis-decay heat}

The decay heats of the simulated assemblies were considered using 3,457 isotopes. Fission products dominate the decay heat of all fuels analysed, and for the UOX fuel it lasted for the first 100 years, as shown in Fig. 7.

\section{Coolant void reactivity}

A negative void coefficient is desirable because an accidental increase in void fraction will reduce reactivity and automatically shut down the chain reaction. It can be observed in Fig. 7 that the spectrum of the MOX and MOX-
Am fuel is harder as compared with the UOX fuel. This has effects on both void and temperature coefficients. Generally, both moderator and temperature coefficients are below the initial criticality as shown in Fig. 8.

Except for MOXAm fuel fabricated from 30-year precooled UOX fuel which showed a positive void coefficient in some configurations, the rest of the MOXAm fuel understudy were with the safety margin. Please note that neutron leakage was not considered in this safety analysis.

Fig. 7

Neutron spectrum of $46 \mathrm{GWd} / \mathrm{T}$ UOX, MOX and MOXAm assemblies at beginning of cycle

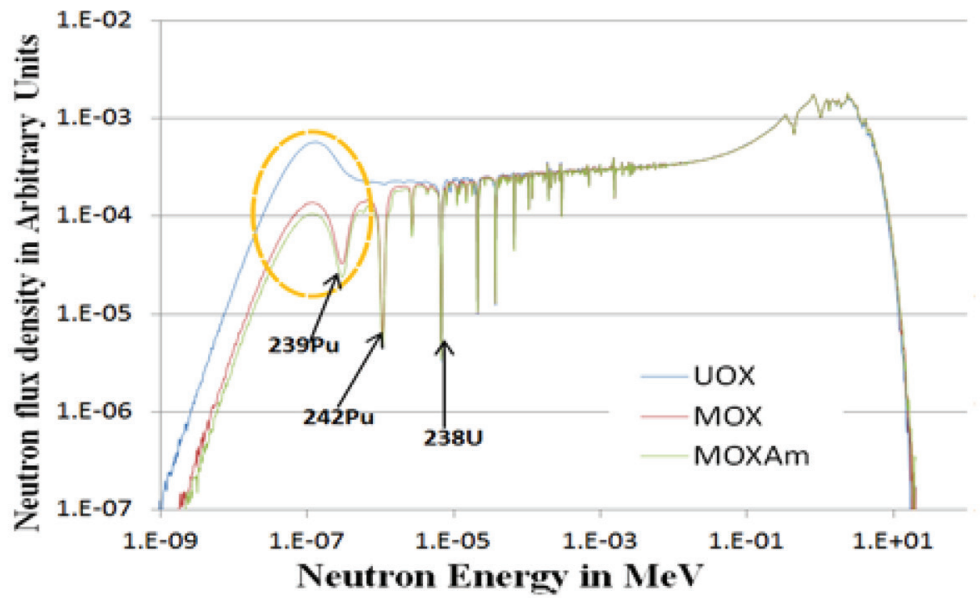




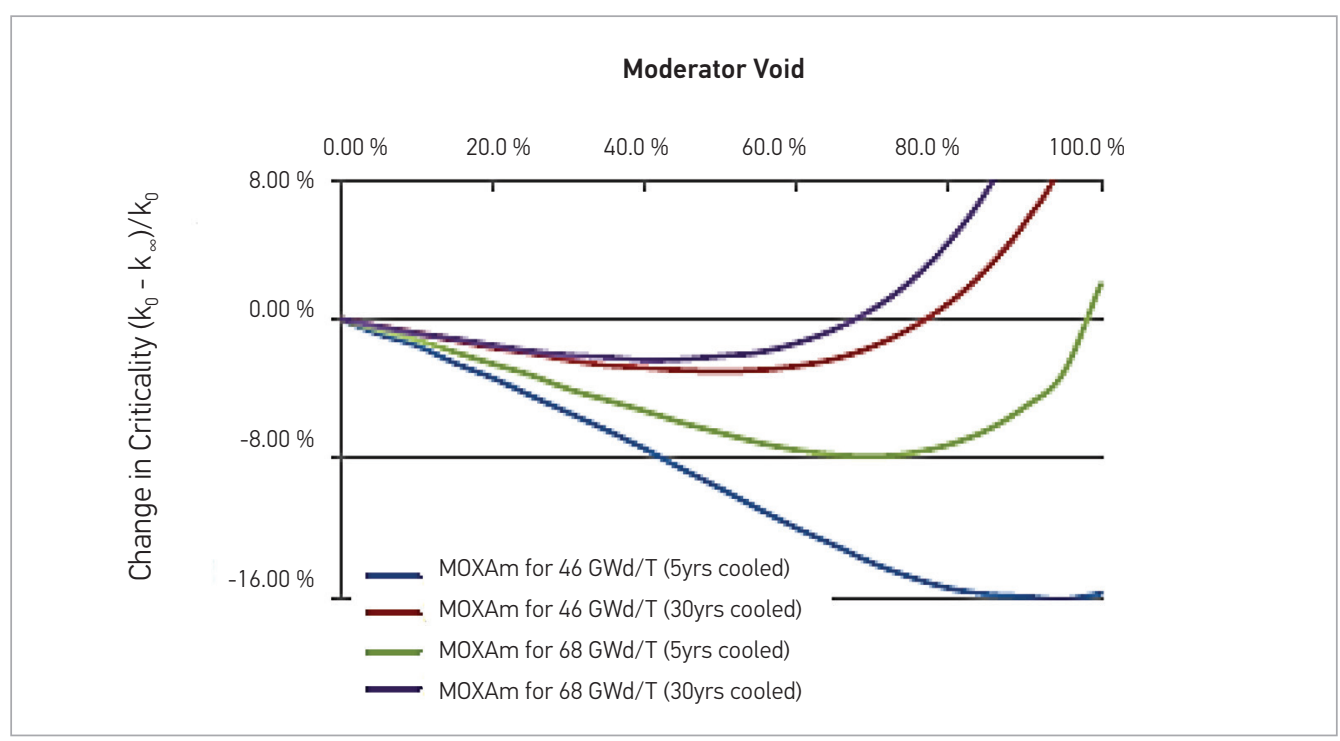

Fig. 8

Coolant void of reactivity for MOXAm assemblies at beginning of cycle (BOC), all fuels from reprocessed spent $46 \mathrm{GWd} / \mathrm{t}$ UOX

\section{Conclusions}

The mono-recycling of americium is intended to reduce radiotoxicity in the UOX glasses, which is bound for geological storage. The results show that, due to the high concentration of Pu in the MOXAm fuel (mixture of $\mathrm{PuO}_{2}$, $\mathrm{UO}_{2}$ and $\mathrm{AmO}_{2}$ ), the radiotoxicity of the MOXAm fuel fabricated from the UOX cycle of longer cooling time and longer burnup maintain their radiotoxicity as compared with the open UOX cycle from which they were fabricated (Fig. 5). However, this makes americium available in the MOXam fuel cycle for incineration (transmutation) when fast reactors become commercialised.

The decay heat of UOX glasses was also reduced due the extraction of $\mathrm{Pu}$ and Am from the UOX spent fuel. This will go a long way to reduce the size of the geo-

\section{Reference}

R. A. Penneman and T. K. Keenan, The radiochemistry of americium and curium, Washington: Subcommittee on Radiochemistry, National Academy of Sciences National Research Council: available from the Office of Technical Services, Dept. of Commerce, (1960).

M. J. Hudson et al., The coordination chemistry of 1,2,4triazinyl bipyridines with lanthanide(III) elements implications for the partitioning of americium(III), Dalton Trans. 9 1675-1685. doi:10.1039/b301178j, (2003). https://doi.org/10.1039/b301178j logical storage needed to permanently store these UOX glasses, as shown in Fig. 6.

All MOXAm fuel types understudied in the PWR cycle showed good safety with the exception of MOXAm assemblies which contained high amount of americium (Fig 8). Such assemblies showed a positive moderator void of reactivity, which could not be consistent with basic safety features due to high Pu content in their fuel configurations.

\section{Acknowlegements}

My sincere thanks go to the staff of the Graduate School of Nuclear and Allied Science, University of Ghana, for their support and also to the scientific staff of Groupe PACS of Institute de Physique Nucleaire of Paris Sud for their support and encouragement.

C. Hill et al., Sanex-BTP Process Development Studies, in Scientific Research on the Back-end of the Fuel Cycle for the 21st Century. Commissariat l'energie atomique., Atalante, 24-26 (October 2000).

$\mathrm{N}$. Capellan, Couplage 3D neutronique thermohydraulique. Developement d'outils pour les tudes de sret des racteurs innovants. Orsay: These de doctorat en science, Universit Paris XI, Nov (2009).

O. M'eplan et al., Coupled Monte Carlo transport with fuel burnup calculation, in MCNP Utility for Reactor Evolution, 
Data Bank Computer Program Services, OECD Nuclear Energy Agency, http://www.oecdnea.org/tools/abstract/detail/ nea-1845, (2009).

O. M'eplan et al., MURE, MCNP Utility for Reactor Evolution, User Guide - Version 1.0 (2009), pp. 73-74.

D. Westl'en, Why Faster is Better - On Minor Actinide Trans- mutation in Hard Neutron Spectra, in Doctoral Thesis, Stockholm, Sweden, KTH School of Engineering Sciences, (2007), p. 37.

ICRP Publication 72, Age dependent doses to members of the public from intake of radionuclides, in Part 5 - compilation of ingestion and inhalation dose coefficient, Annals of the ICRP, 26:1, (1996).

\title{
Americio perdirbimas prancūziškame suslègtojo vandens reaktoriuje ir kuro rodiklių (išdegimo, radioaktyvumo, likutinès šilumos bei saugos) neutroniniai tyrimai
}

\author{
Robert Bright Mawuko Sogbadji \\ Ganos atominės energetikos komisija, Nacionalinis branduolinių tyrimų institutas, Gana
}

\section{Sylvain David}

Branduokinès fizikos intitutas, Prancūzija

\section{Edward Akaho, Benjamin Jabez Botwe Nyarko}

Ganos universitetas, Branduolio fizikos ir taikomujų mokslu aukštoji mokykla, Gana

Aktinidų, turinčių ilgą pusejjimo trukmę, perdirbimas iki šių dienų nebuvo galimas, išskyrus plutoni (Pu). Šis tyrimas skirtas aktinidu branduolinio kuro atlieku mažinimui. Urano oksido kuro (UOX) rinkiniai (angl. assembly), kaip atviro ciklo sistema, buvo sukurti pasiekti 46GWd/T ir 68GWd/T išdegimą naudojant MURE kodą. MURE kodas sudarytas iš statinio Monte Karlo kodo ir skaičiavimu, atliktų kuro evoliucijos spinduliavimo ir aušinimo laikotarpiais. MURE kodas buvo naudojamas pagrindiniu problemu, susijusiu su americio (Am) mono-perdirbimu prancūziškame suslègtojo vandens reaktoriuoje (angl. French pressurised water reactors - PWR). Tikslas buvo sumažinti americio kieki kuro cikle ir nustatyti saugu americio kieki, kuris galètų būti jivestas i maišytų oksidu (MOX) kurą. Panaudotas UOX kuras buvo perdirbtas ir pritaikytas MOX gamybai, išgaunant plutoni bei pridedant nuskaidrintojo urano, tam, kad būtų pasiektas reikiamas $46 \mathrm{GWd} / \mathrm{T}$ ir $68 \mathrm{GWd} / \mathrm{T}$ išdegimas, atsižvelgiant i panaudoto UOX aušinimo dažnumą surinkimo saugykloje. Taip at šiame darbe buvo tiriamas aušinimo laiko poveikis išdegimui ir radioaktyvumui. 30 metu aušinimo saugykloje išbuvusiam UOX kurui, del Pu-241 irimo reikia didesnès Pu koncentracijos, tam, kad būtu galima perdirbti i MOX kurą. Americis, kurio vidutinè pusèjimo trukmè yra 432 metų, turi aukštą radioaktyvumo lygi, aukštą likutinę šilumą ir yra gali būti laikomas kitų ilgaamžių izotopu prototipu. Nauja strategija, kurios siekiama, turètu būti ne tik perdirbti Pu iš panaudoto UOX kuro, bet ir americio izotopus, kurie sąlygoja atliekų radioaktyvumą. Americio mono-perdirbimas nèra galutinis sprendimas, nes viena kartą per MOX ciklą perleidus Am naudojant suslègto vandens reaktorius (PWR) nepakanka sunaikinti visą americi. Pagrindinis tikslas yra pasiūlyti “laukimo strategiją” abiems Am ir Pu panaudotame kure, taip, kad jie taptų prieinami tolesnèms virsmy strategijoms.

MOX ir americio izotopu (MOXam) kuras buvo pagamintas, kad nustatyti americio poveiki MOX kuro išdegimui, neutronu veikimui bei radioaktyvumui. MOXam kuras parode sąlyginai gerus rodikliu, tokių kaip išdegimas ir radioaktyvumas rezultatus. A 68GWd/T MOX kuro rinkiniai iš perdirbto panaudoto $45 \mathrm{Wd} / \mathrm{T} \mathrm{UOX}$ kuro, parode sumažejusi radioaktyvumą lyginant su atviru ciklu. Visi tirti kuro tipai po PWR ciklo parode geras saugumo savybes, išskyrus kai kuriuos MOXAm mėginius, kur esant specifinèms sąlygoms buvo nustatymas teigiamas koeficientas (angl. void coefcient), kas neatitinka saugumo reikalavimų.

Raktiniai žodžiai: radioaktyvumas, išdegimas, americio oksidas, aušinimo laikas. 